\title{
Contrasting Characteristics of Lodging Resistance in Two Super-Rice Hybrids Differing in Harvest Index
}

\author{
Zui Tao ${ }^{1}$, Tao Lei ${ }^{1}$, Fangbo Cao ${ }^{1}$, Jiana Chen ${ }^{1}$, Xiaohong Yin ${ }^{1,2}$, Tianfeng Liang ${ }^{2, *}$ and Min Huang ${ }^{1, *}$ \\ ${ }^{1}$ Crop and Environment Research Center, College of Agronomy, Hunan Agricultural University, Changsha, 410128, China \\ ${ }^{2}$ Guangxi Key Laboratory of Rice Genetics and Breeding, Rice Research Institute, Guangxi Academy of Agricultural Sciences, \\ Nanning, 530007, China \\ ${ }^{*}$ Corresponding Authors: Tianfeng Liang. Email: tfliang@gxaas.net; Min Huang. Email: mhuang@hunau.edu.cn
}

Received: 13 April 2021 Accepted: 31 May 2021

\begin{abstract}
The "super rice" breeding program in China has been successful in developing high-yielding hybrids, including few with high harvest index values. However, there is limited information on the relationship between lodging resistance and harvest index, and the mechanisms underlying the relationship in super-rice hybrids. In this study, a two-year field experiment was conducted to compare lodging resistance and its related traits between two superrice hybrids differing in harvest index, i.e., Guiliangyou 2 (G2) with a high harvest index and Y-liangyou 1 (Y1) with a typical harvest index of modern high-yielding rice varieties. Results showed that compared to Y1, G2 was lower in plant height due to its lower aboveground $\mathrm{N}$ uptake, and its higher stem breaking resistance (i.e., lower stem breaking index) resulted from a lower stem height at its center of gravity. Consequently, G2 had a higher lodging resistance (i.e., lower plant lodging index) than Y1. This study suggests that developing super-rice hybrids with high harvest index values is a possible way to achieve both high grain yield and strong lodging resistance in rice.
\end{abstract}

\section{KEYWORDS}

Harvest index; nitrogen uptake; plant height; lodging resistance; stem breaking resistance; super-rice hybrid

\section{Introduction}

Self-sufficiency in rice (Oryza sativa L.) production is important to ensure food security in China, where approximately $65 \%$ of the population consumes rice as a staple food [1]. Although China's production of rice is currently self-sufficient, developments to further increase rice yields from existing or even declining arable lands is crucial to feed the growing population sustainably [2,3]. To achieve this goal, China initiated a national program in 1996 to develop "super rice" based on the ideotype concept [4]. Soon afterwards, in 1998, Prof. Longping Yuan, known as the "Father of Hybrid Rice", proposed a strategy for developing super-rice hybrids by combining an ideotype approach with heterosis breeding [5]. This combined strategy has been a major success in developing super-rice hybrids with high grain yields over the past two decades [6,7]. Up to 2020, a total of 99 hybrids have been approved as super rice by the Ministry of Agriculture of China (http://www.ricedata.cn/variety/superice.htm). 
Increases in grain yield can be achieved by increasing biomass production and/or the harvest index (i.e., the fraction of the biomass allocated to the grains) of rice. Generally, the improvement of potential grain yield due to the development of super-rice hybrids has been mainly attributed to an increase in biomass production [8]. Interestingly, it is found that there are a few of the super-rice hybrids with high harvest index but low biomass production. For example, the super-rice hybrid Guiliangyou 2 (G2) has an average harvest index of about $0.55[9,10]$, which is $10 \%$ higher than that $(\sim 0.50)$ of modern highyielding rice varieties [11]. The high harvest index in G2 can compensate for its low biomass production and consequently enable the grain yield to be maintained at a high level $[9,10]$.

In addition to being a yield determinant, the harvest index is closely related to several other important traits in rice, such as lodging resistance. During the Green Revolution in the 1960s, the introduction of semidwarf genes increased harvest index values from 0.3 to 0.5 by reducing plant height, and meanwhile, increased lodging resistance in rice [11,12]. However, there is little understanding of the relationship between lodging resistance and harvest index and the mechanisms underlying the relationship in superrice hybrids. Plant height and stem-breaking resistance affect lodging resistance [13-15], but little to no information is available on how these two factors may be altered in super-rice hybrids with high harvest index values. As mentioned above, breeding ideotypes is a key approach in the development of super-rice hybrids. It has been well-documented that panicle size and the three leaves from the top are generally larger in super-rice hybrids in comparison to those of ordinary hybrids and inbreds $[6,8,10,16]$. However, limited reports are available on whether these enlargements of traits in super-rice hybrids result in a topheavy plant with a higher center of gravity, and consequently a plant more susceptible to lodging. To address these knowledge gaps, the present study compared characteristics of lodging resistance between two super-rice hybrids differing in harvest index.

\section{Materials and Methods}

\subsection{Site and Soil}

Field experiments were conducted at the research farm of the Crop and Environment Research Center $\left(28^{\circ} 09^{\prime} \mathrm{N}, 113^{\circ} 37^{\prime} \mathrm{E}, 43 \mathrm{~m}\right.$ asl), Hunan Agricultural University, China in 2019 and 2020. The research farm had a moist subtropical monsoon climate with average daily mean temperatures of 28.2 and $28.1^{\circ} \mathrm{C}$ and solar radiation of 16.8 and $15.6 \mathrm{MJ} \mathrm{m}^{-2}$ in the rice-growing season in 2019 and 2020, respectively (Figs. 1A and 1B). The soil texture of the experimental field was clay with the following chemical properties at the upper 20-cm layer: $\mathrm{pH} 6.16,34.8 \mathrm{~g} \mathrm{~kg}^{-1}$ organic matter, $140 \mathrm{mg} \mathrm{kg}-1$ available nitrogen (N), $28.9 \mathrm{mg} \mathrm{kg}^{-1}$ available phosphorus (P), and $118 \mathrm{mg} \mathrm{kg}^{-1}$ available potassium (K).

\subsection{Plants Materials}

Two super-rice hybrids, G2 and Y-liangyou 1 (Y1), were used in the experiment. G2 and Y1 were developed by the Guangxi Academy of Agricultural Sciences in 2008 and the Hunan Hybrid Rice Research Institute in 2006 and approved as super rice by the Ministry of Agriculture of China in 2010 and 2006, respectively. These two hybrids were selected because (1) they differ in their harvest index values by more than $10 \%$ with that of G2 greater than that of Y1 [10], and (2) Y1 well-represents super-rice hybrids because it has been widely grown in China with a cumulative growing area of more than 2.5 million ha (http://www.ricedata.cn/variety/varis/604222.htm).

In each experimental year, G2 and Y1 plots were laid out in a randomized complete-block design with four replicate plots per hybrid and a plot size of $60 \mathrm{~m}^{2}(10 \mathrm{~m} \times 6 \mathrm{~m})$. Pre-germinated seeds were sown in a seedbed on 05 May to raise seedlings. On 25 May, the seedlings were manually uprooted and transplanted into the plots. Transplanting was done at a plant spacing of $20 \mathrm{~cm} \times 20 \mathrm{~cm}$ with two seedlings per hill. Chemical N, P, and $\mathrm{K}$ fertilizers were applied according to the local recommendations. The $\mathrm{N}$ fertilizer $\left(150 \mathrm{~kg} \mathrm{~N} \mathrm{ha}^{-1}\right)$ was applied in three parts: $50 \%$ as basal fertilizer, $30 \%$ at the early-tillering stage, and 
$20 \%$ at the panicle initiation stage. All of the $\mathrm{P}$ fertilizer $\left(75 \mathrm{~kg} \mathrm{P}_{2} \mathrm{O}_{5} \mathrm{ha}^{-1}\right)$ was applied as basal fertilizer. The $\mathrm{K}$ fertilizer $\left(150 \mathrm{~kg} \mathrm{~K}_{2} \mathrm{O} \mathrm{ha}{ }^{-1}\right)$ was split equally to apply as basal fertilizer and at the panicle initiation stage. A floodwater depth of 5-10 cm was maintained in the plots from transplanting until seven days before maturity, when the plots were drained in preparation for harvesting. Pathogens, insects, and weeds were intensively controlled by using agrochemicals throughout the growing season.
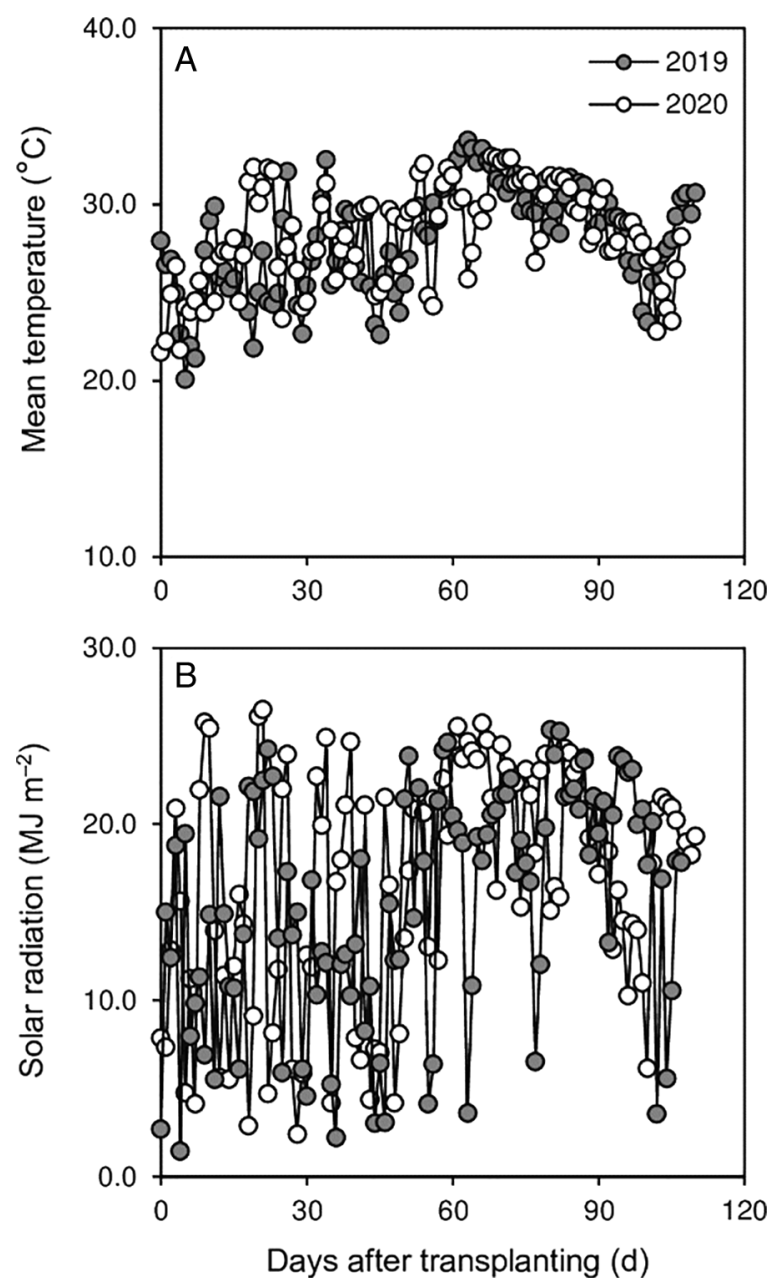

Figure 1: Daily mean temperature (A) and solar radiation (B) during the rice-growing season (from transplanting to maturity) in 2019 and 2020

\subsection{Sampling and Measurements}

Twenty main stems that headed on the same day were tagged in each plot. At 25 days after heading, 10 tagged stems were sampled from each plot to measure stem height at the center of gravity. Length (i.e., the distance between two nodes), external and internal diameters, and breaking load (i.e., the amount of force required to break an internode) were recorded from the second internode from the base. After measuring breaking load, each broken stem from the point of breakage at the second internode from the base to the panicle tip was measured for its length $\left(\mathrm{L}_{\mathrm{BP}-\mathrm{PT}}\right)$ and fresh weight $\left(\mathrm{FW}_{\mathrm{BP}-\mathrm{PT}}\right)$. The breaking load was measured using a stalk strength tester (YYD-1, Zhejiang Top Instrument Co. Ltd., Hangzhou, China). Wall thickness (external diameter/2-internal diameter/2), breaking strength (breaking load $\times$ 
internode length/4), bending moment of stem $\left(\mathrm{L}_{\mathrm{BP}-\mathrm{PT}} \times \mathrm{FW}_{\mathrm{BP}-\mathrm{PT}}\right)$, and stem breaking index (breaking strength/bending moment of stem) were calculated from the data measured from the second internode from the base.

On the same day, 100 plants were randomly selected in each plot to determine average number of tillers per individual, and 10 plants with the average tiller number (which was 8 tillers for G2 in both 2019 and 2020; and 8 and 9 tillers for Y1 in 2019 and 2020, respectively) were chosen to determine plant lodging load (i.e., the amount of lateral force required to bend the whole plant to a $45^{\circ}$ angle from the vertical plane), plant height, and aboveground fresh weight. A prostrate tester (DIK-7401, Daiki Rika Kogyo Co. Ltd., Tokyo, Japan) was set up perpendicular to the plant at a height of $20 \mathrm{~cm}$ above the soil surface to measure the lodging load according to the method of Kashiwagi et al. [17]. Plant lodging index values were calculated by (plant height $\times$ aboveground fresh weight $) /($ lodging load $\times 20$ ).

Another 10 plants with the average tiller number were sampled from each plot at each of the heading and maturity stages. The plants sampled at heading were separated into stems, leaves, and panicles and then ovendried at $70^{\circ} \mathrm{C}$ to constant weights. The oven-dried samples were ground to a powder and approximately $0.5 \mathrm{~g}$ of each powder was digested with a mixture of $\mathrm{H}_{2} \mathrm{SO}_{4}-\mathrm{H}_{2} \mathrm{O}_{2}$ to determine $\mathrm{N}$ content with a segmented flow analyzer (Skalar SAN Plus, Skalar Inc., Breda, The Netherlands). Aboveground N uptake was calculated by multiplying the dry weight by the $\mathrm{N}$ content. N-use efficiency for plant height growth $\left(\mathrm{NUE}_{\mathrm{PH}}\right)$ was calculated by dividing the plant height by the aboveground $\mathrm{N}$ uptake. The sampled mature plants were hand threshed, and filled and unfilled grains were separated by submerging them in tap water. Straw and filled and unfilled grains were oven-dried at $70^{\circ} \mathrm{C}$ to constant weights to determine aboveground biomass (the sum of dry weights of straw and filled unfilled grains) and grain yield (the dry weight of filled grains only). Harvest index was calculated by dividing grain yield by aboveground biomass.

\subsection{Statistical Analysis}

Data were subjected to analysis of variance (ANOVA) using Statistix 8.0 (Analytical Software, Tallahassee, FL, USA). The statistical model of the ANOVA included replication (experimental plot), hybrid, year, and the interaction between hybrid and year, and the significance level was set at $P<0.05$. Because the interaction between hybrid and year on the plant lodging index (the most important target parameter) was not significant $(P=0.76)$, only the statistical results for comparing means of hybrids across two years are presented and described below.

\section{Results}

\subsection{Harvest Index, Aboveground Biomass, and Grain Yield}

The differences in harvest index and aboveground biomass were significant between G2 and Y1 (Tab. 1). The harvest index was 10\% higher in G2 than in Y1. On the contrary, the aboveground biomass was $10 \%$ lower in G2 than in Y1. Grain yield was the same between G2 and Y1.

\subsection{Plant Lodging Characteristics}

There were significant differences in plant lodging index, plant height, and aboveground fresh weight between G2 and Y1 (Tab. 2). The plant lodging index was 26\% lower in G2 compared to Y1. The plant height and aboveground fresh weight in G2 were $6 \%$ and $17 \%$ lower than those in Y1, respectively. There was no significant difference in plant lodging load between G2 and Y1.

The differences in aboveground $\mathrm{N}$ uptake at heading and $\mathrm{NUE}_{\mathrm{PH}}$ were significant between $\mathrm{G} 2$ and $\mathrm{Y} 1$ (Tab. 3). The aboveground $\mathrm{N}$ uptake at heading in G2 was 19\% lower than that in Y1. On the contrary, the $\mathrm{NUE}_{\mathrm{PH}}$ was $14 \%$ higher in $\mathrm{G} 2$ than in $\mathrm{Y} 1$. 
Table 1: Harvest index, aboveground biomass, and grain yield in two super-rice hybrids, Guiliangyou 2 (G2) and Y-liangyou 1 (Y1), grown in 2019 and 2020

\begin{tabular}{lllll}
\hline Hybrid & Year & Harvest index & Aboveground biomass $\left(\mathrm{g} \mathrm{plant}^{-1}\right)$ & Grain yield $\left(\mathrm{g} \mathrm{plant}^{-1}\right)$ \\
\hline $\mathrm{G} 2$ & 2019 & 0.51 & 58.9 & 30.0 \\
& 2020 & 0.56 & 59.3 & 33.3 \\
& Mean & $0.54 \mathrm{a}$ & $59.1 \mathrm{~b}$ & $31.7 \mathrm{a}$ \\
& SE & 0.01 & 0.9 & 0.7 \\
Y1 & 2019 & 0.44 & 68.1 & 30.0 \\
& 2020 & 0.53 & 62.8 & 33.4 \\
& Mean & $0.49 \mathrm{~b}$ & $65.5 \mathrm{a}$ & $31.7 \mathrm{a}$ \\
& SE & 0.02 & 1.4 & 0.8 \\
\hline
\end{tabular}

Note: Within a column, means followed by different letters are significantly different from each other at the 0.05 probability level.

Table 2: Plant lodging index and related traits at 25 days after heading in two super-rice hybrids, Guiliangyou 2 (G2) and Y-liangyou 1 (Y1), grown in 2019 and 2020

\begin{tabular}{llllll}
\hline Hybrid & Year & $\begin{array}{l}\text { Plant lodging } \\
\text { index }\end{array}$ & $\begin{array}{l}\text { Plant height } \\
(\mathrm{cm})\end{array}$ & $\begin{array}{l}\text { Aboveground fresh weight } \\
(\mathrm{g} \mathrm{plant})\end{array}$ & $\begin{array}{l}\text { Plant lodging load } \\
(\mathrm{g})\end{array}$ \\
\hline G2 & 2019 & 3.17 & 121 & 191 & 364 \\
& 2020 & 7.23 & 118 & 163 & 133 \\
& Mean & $5.20 \mathrm{~b}$ & $120 \mathrm{~b}$ & $177 \mathrm{~b}$ & $249 \mathrm{a}$ \\
& SE & 1.14 & 1 & 7 & 48 \\
Y1 & 2019 & 4.41 & 132 & 227 & 340 \\
& 2020 & 9.63 & 121 & 199 & 125 \\
& Mean & $7.02 \mathrm{a}$ & $127 \mathrm{a}$ & $213 \mathrm{a}$ & $233 \mathrm{a}$ \\
\hline
\end{tabular}

Note: Within a column, means followed by different letters are significantly different from each other at the 0.05 probability level.

Table 3: Aboveground nitrogen $(\mathrm{N})$ uptake at heading and N-use efficiency for plant height growth (NUE $\mathrm{PH})$ in two super-rice hybrids, Guiliangyou 2 (G2) and Y-liangyou 1 (Y1), grown in 2019 and 2020

\begin{tabular}{llll}
\hline Hybrid & Year & Aboveground N uptake $\left(\mathrm{mg} \mathrm{plant}^{-1}\right)$ & NUE $_{\mathrm{PH}}\left(\mathrm{cm} \mathrm{mg}^{-1}\right)$ \\
\hline G2 & 2019 & 525 & 0.23 \\
& 2020 & 485 & 0.24 \\
& Mean & $505 \mathrm{~b}$ & $0.24 \mathrm{a}$ \\
& SE & 15 & 0.01 \\
Y1 & 2019 & 668 & 0.20 \\
& 2020 & 575 & 0.21 \\
& Mean & $622 \mathrm{a}$ & $0.21 \mathrm{~b}$ \\
& SE & 24 & 0.01 \\
\hline
\end{tabular}

Note: Within a column, means followed by different letters are significantly different from each other at the 0.05 probability level. 
Stem breaking index, bending moment of stem, and $\mathrm{L}_{\mathrm{BP}-\mathrm{PT}}$ were significantly different between $\mathrm{G} 2$ and $\mathrm{Y} 1$, whereas their differences in breaking-related traits of the second internode from the base (i.e., breaking strength, internode length, and breaking load) and $\mathrm{FW}_{\mathrm{BP}-\mathrm{PT}}$ were not significant (Tab. 4). G2 had 17\% lower stem breaking index compare to $\mathrm{Y} 1$. The bending moment of stem and $\mathrm{L}_{\mathrm{BP}-\mathrm{PT}}$ were $15 \%$ and $10 \%$ lower in $\mathrm{G} 2$ than those in $\mathrm{Y} 1$, respectively.

Table 4: Stem breaking index, breaking-related traits of the second internode from the base, and bendingrelated traits of stem at 25 days after heading in two super-rice hybrids, Guiliangyou 2 (G2) and Y-liangyou 1 (Y1), grown in 2019 and 2020

\begin{tabular}{|c|c|c|c|c|c|c|c|}
\hline \multirow[t]{2}{*}{ Year } & \multirow[t]{2}{*}{$\begin{array}{l}\text { Stem breaking } \\
\text { index }\end{array}$} & \multicolumn{3}{|c|}{$\begin{array}{l}\text { Breaking-related traits of the second } \\
\text { basal internode }\end{array}$} & \multicolumn{3}{|c|}{ Bending-related traits of stem } \\
\hline & & $\begin{array}{l}\text { Breaking } \\
\text { strength } \\
(\mathrm{g} \mathrm{cm})\end{array}$ & $\begin{array}{l}\text { Internode } \\
\text { length } \\
(\mathrm{cm})\end{array}$ & $\begin{array}{l}\text { Breaking } \\
\text { load } \\
(\mathrm{g}) \\
\end{array}$ & $\begin{array}{l}\text { Bending moment } \\
(\mathrm{g} \mathrm{cm})\end{array}$ & $\begin{array}{l}\mathrm{L}_{\mathrm{BP}-\mathrm{PT}} \\
(\mathrm{cm})\end{array}$ & $\begin{array}{l}\mathrm{FW}_{\mathrm{BP}-\mathrm{PT}} \\
\left(\mathrm{g} \mathrm{stem}^{-1}\right)\end{array}$ \\
\hline \multicolumn{8}{|l|}{$\mathrm{G} 2$} \\
\hline 2019 & 0.58 & 3673 & 7.07 & 2078 & 2121 & 101 & 21.0 \\
\hline 2020 & 0.59 & 3411 & 6.37 & 2142 & 2027 & 105 & 19.3 \\
\hline Mean & $0.59 \mathrm{~b}$ & $3542 \mathrm{a}$ & $6.72 \mathrm{a}$ & $2110 \mathrm{a}$ & $2074 \mathrm{~b}$ & $103 \mathrm{~b}$ & $20.2 \mathrm{a}$ \\
\hline $\mathrm{SE}$ & 0.02 & 98 & 0.19 & 53 & 71 & 1 & 0.6 \\
\hline \multicolumn{8}{|l|}{ Y1 } \\
\hline 2019 & 0.73 & 3833 & 7.49 & 2047 & 2808 & 120 & 23.4 \\
\hline 2020 & 0.68 & 3049 & 5.27 & 2314 & 2063 & 108 & 19.1 \\
\hline Mean & $0.71 \mathrm{a}$ & $3441 \mathrm{a}$ & $6.38 \mathrm{a}$ & $2181 \mathrm{a}$ & $2436 \mathrm{a}$ & $114 \mathrm{a}$ & $21.3 \mathrm{a}$ \\
\hline SE & 0.02 & 167 & 0.45 & 91 & 147 & 2 & 0.9 \\
\hline
\end{tabular}

Note: $\mathrm{L}_{\mathrm{BP}-\mathrm{PT}}$ is the length measured from each stem's broken point at the second internode from the base to the panicle tip; $\mathrm{FW}_{\mathrm{BP}-\mathrm{PT}}$ is the fresh weight of the same stem. Within a column, means followed by different letters are significantly different from each other at the 0.05 probability level.

There was significant difference in stem height at the center of gravity between G2 and Y1 (Tab. 5). G2 had 8\% lower stem height at the center of gravity than Y1. The differences in cross-sectional traits of the second internode from the base, i.e., external and internal diameter and wall thickness, were not significant between G2 and Y1.

\section{Discussion}

Here, we confirmed the findings of previous studies that the super-rice hybrid G2 has a high harvest index $[9,10]$. This study also showed that a higher harvest index may have compensated for the lower aboveground biomass production in G2 compared to that in the widely-grown super-rice hybrid Y1 with a typical harvest index $(\sim 0.50)$ of modern high-yielding rice varieties [11], based on the equal grain yields between the two super-rice hybrids. This finding supports previous reports' conclusion that a higher harvest index is a feasible way to achieve high grain yield in rice $[9,10]$. 
Table 5: Stem height at the center of gravity and cross-sectional traits of the second internode from the base at 25 days after heading in two super-rice hybrids, Guiliangyou 2 (G2) and Y-liangyou 1 (Y1), grown in 2019 and 2020

\begin{tabular}{llllll}
\hline Hybrid & Year & $\begin{array}{l}\text { Stem height } \\
\text { at the center } \\
\text { of gravity }(\mathrm{cm})\end{array}$ & $\begin{array}{l}\text { External diameter } \\
(\mathrm{mm})\end{array}$ & $\begin{array}{l}\text { Internal diameter } \\
(\mathrm{mm})\end{array}$ & $\begin{array}{l}\text { Wall thickness } \\
(\mathrm{mm})\end{array}$ \\
\hline G2 & 2019 & 47.6 & 6.24 & 3.68 & 1.28 \\
& 2020 & 48.8 & 6.43 & 3.19 & 1.62 \\
& Mean & $48.2 \mathrm{~b}$ & $6.34 \mathrm{a}$ & $3.44 \mathrm{a}$ & $1.45 \mathrm{a}$ \\
& $\mathrm{SE}$ & 0.5 & 0.09 & 0.15 & 0.09 \\
$\mathrm{Y} 1$ & 2019 & 53.7 & 6.46 & 3.60 & 1.43 \\
& 2020 & 50.7 & 6.01 & 3.48 & 1.26 \\
& Mean & $52.2 \mathrm{a}$ & $6.24 \mathrm{a}$ & $3.54 \mathrm{a}$ & $1.35 \mathrm{a}$ \\
& $\mathrm{SE}$ & 1.0 & 0.09 & 0.12 & 0.07 \\
\hline
\end{tabular}

Note: Within a column, means followed by different letters are significantly different from each other at the 0.05 probability level.

More importantly, this study revealed contrasting characteristics of lodging resistance between G2 and Y1. Namely, G2 had a higher plant lodging resistance (i.e., lower plant lodging index) than Y1. Because plant lodging load was comparable between G2 and Y1, the higher lodging resistance in G2 was attributable to its lower plant height and aboveground fresh weight than those in Y1. These findings indicate that super-rice hybrids with high harvest index values increase their resistance to lodging by having lower plant height and aboveground fresh weight. This is congruent with the phenomenon observed in the Green Revolution [12] where the rice varieties developed at that time had greater harvest index values because their semidwarf genes effectively reduced plant height and consequently increased lodging resistance. Though there is limited information on the molecular mechanisms involved in the regulation of plant height in superrice hybrids with high harvest index values, the results of this study indicate that the lower plant height in $\mathrm{G} 2$ resulted from a reduction in aboveground $\mathrm{N}$ uptake compared to that in $\mathrm{Y} 1$ because the $\mathrm{NUE}_{\mathrm{PH}}$ was higher in G2 than in Y1. This outcome suggests that further investigations on the molecular mechanisms regulating plant height in super-rice hybrids with high harvest index values can focus on the genes related to $\mathrm{N}$ uptake.

In addition, it has been well documented that lodging resistance is closely related to stem breaking resistance in rice [13-15]. Consistently, in this study, the higher lodging resistance in G2 than in Y1 could also be explained by a higher stem breaking resistance (i.e., a lower stem breaking index). Furthermore, the results of this study indicate that the higher stem breaking resistance in G2 was mainly attributable to the lower value of the bending moment of stem that resulted from lower $\mathrm{L}_{\mathrm{BP}-\mathrm{PT}}$, as well as the insignificant differences in stem breaking strength and related traits of the second internode. This finding was also supported by other stem traits. Namely, stem height at the center of gravity was lower in G2 compared to that in Y1, whereas their cross-sectional traits of the second internode from the base were not significantly different. The results of this study suggest that a top-heavy plant with a high center of gravity is more susceptible to lodging and can be avoided by the development of super-rice hybrids with high harvest index values. 


\section{Conclusion}

Compared to the widely-grown super-rice hybrid Y1 with a typical harvest index of modern highyielding rice varieties, the super-rice hybrid G2 with a high harvest index measured lower in plant height due to its lower aboveground $\mathrm{N}$ uptake, its higher stem breaking resistance resulted from a lower stem height at its center of gravity, and consequently exhibited higher lodging resistance.

Funding Statement: This study was supported by the National Natural Science Foundation of China (31771722) and the Open Fund of the Guangxi Key Laboratory of Rice Genetics and Breeding (2018-15Z06-KF17).

Conflicts of Interest: The authors declare that they have no conflicts of interest to report regarding the present study.

\section{References}

1. Hsiaoping, C. (2005). Rice consumption in China: Can China change rice consumption from quantity to quality. In: Toriyama, K., Heong, K. L., Hardy, B. (Eds.), Rice is life: Scientific perspectives for the 21st Century, pp. 497499. Los Baños, Philippines: International Rice Research Institute.

2. Huang, M., Zou, Y. (2018). Integrating mechanization with agronomy and breeding to ensure food security in China. Field Crops Research, 224, 22-27. DOI 10.1016/j.fcr.2018.05.001.

3. Deng, N., Grassini, P., Yang, H., Huang, J., Cassman, K. G. et al. (2017). Closing yield gaps for rice selfsufficiency in China. Nature Communications, 11, 1725. DOI 10.1038/s41467-019-09447-9.

4. Tang, L., Xu, Z., Chen, W. (2017). Advances and prospects of super rice breeding in China. Journal of Integrative Agriculture, 16, 984-991. DOI 10.1016/S2095-3119(16)61604-0.

5. Yuan, L. (2001). Breeding of super hybrid rice. In: Peng, S., Hardy, B. (Eds.), Rice research for food security and poverty alleviation. pp. 143-149. Los Baños, Philippines: International Rice Research Institute.

6. Peng, S., Khush, G. S., Virk, P., Tang, Q., Zou, Y. (2008). Progress in ideotype breeding to increase rice yield potential. Field Crops Research, 108, 32-38. DOI 10.1016/j.fcr.2008.04.001.

7. Huang, M., Tang, Q., Ao, H., Zou, Y. (2017). Yield potential and stability in super hybrid rice and its production strategies. Journal of Integrative Agriculture, 16, 1009-1017. DOI 10.1016/S2095-3119(16)61535-6.

8. Zhang, Y., Tang, Q., Zou, Y., Li, D., Qin, J. et al. (2009). Yield potential and radiation use efficiency of super hybrid rice grown under subtropical conditions. Field Crops Research, 114, 91-98. DOI 10.1016/j. fcr.2009.07.008.

9. Huang, M., Yin, X., Jiang, L., Zou, Y., Deng, G. (2015). Raising potential yield of short-duration rice cultivars is possible by increasing harvest index. Biotechnology, Agronomy, Society and Environment, 19, 153-159.

10. Huang, M., Chen, J., Cao, F., Jiang, L., Zou, Y. et al. (2016). Improving physiological N-use efficiency by increasing harvest index in rice: A case in super-hybrid cultivar Guiliangyou 2. Archives of Agronomy and Soil Science, 62, 725-743. DOI 10.1080/03650340.2015.1082031.

11. Zhang, H., Chen, T., Liu, L., Wang, Z., Yang, J. et al. (2013). Performance of grain yield and physiological traits of rice in the Yangtze river basin of China during the last $60 \mathrm{yr}$. Journal of Integrative Agriculture, 12, 57-66. DOI 10.1016/S2095-3119(13)60205-1.

12. Ferrero-Serrano, Á., Cantos, C., Assmann, S. M. (2019). The role of dwarfing traits in historical and modern agriculture with a focus on rice. Cold Spring Harbor Perspectives in Biology, 11, a034645. DOI 10.1101/ cshperspect.a034645.

13. Islam, M. S., Peng, S., Visperas, R. M., Ereful, N., Bhuiya, M. S. U. (2007). Lodging-related morphological traits of hybrid rice in a tropical irrigated ecosystem. Field Crops Research, 101, 240-248. DOI 10.1016/j. fcr.2006.12.002.

14. Wu, W., Huang, J., Cui, K., Nie, L., Wang, Q. et al. (2012). Sheath blight reduces stem breaking resistance and increases lodging susceptibility of rice plants. Field Crops Research, 128, 101-108. DOI 10.1016/j. fcr.2012.01.002. 
Phyton, 2022, vol.91, no.2

15. Zhang, W., Wu, L., Wu, X., Ding, Y., Li, G. et al. (2016). Lodging resistance of japonica rice (Oryza sativa L.): Morphological and anatomical traits due to top-dressing nitrogen application rates. Rice, 9, 31. DOI 10.1186/ s12284-016-0103-8.

16. Huang, M., Zou, Y., Jiang, P., Xia, B., Ibrahim, M. et al. (2011). Relationship between grain yield and yield components in super hybrid rice. Agricultural Sciences in China, 10, 1537-1544. DOI 10.1016/S1671-2927 (11)60149-1.

17. Kashiwagi, T., Ishimaru, K. (2004). Identification and functional analysis of a locus for improvement of lodging resistance in rice. Plant Physiology, 134, 676-683. DOI 10.1104/pp.103.029355. 